Research Article

\title{
Analysis of Failure Mechanism of Roadway Surrounding Rock under Thick Coal Seam Strong Mining Disturbance
}

\author{
Fuzhou Qi ${ }^{D},{ }^{1}$ Dangwei Yang, ${ }^{2}$ Yuguo Zhang, ${ }^{1}$ and Yuxi Hao ${ }^{1}$ \\ ${ }^{1}$ School of Civil \& Architecture Engineering, Zhongyuan University of Technology, Zhengzhou 450007, Henan, China \\ ${ }^{2}$ Pingdingshan Coal No.10 Mine, Pingdingshan 467000, Henan, China
}

Correspondence should be addressed to Fuzhou Qi; 18255416386@163.com

Received 26 March 2021; Accepted 2 June 2021; Published 19 June 2021

Academic Editor: Guangyao Si

Copyright (c) 2021 Fuzhou Qi et al. This is an open access article distributed under the Creative Commons Attribution License, which permits unrestricted use, distribution, and reproduction in any medium, provided the original work is properly cited.

Severe dynamic disturbance in extrathick coal seam mining has become one of the main factors threatening the stability of roadway surrounding rock. In this article, the \#6 thick coal seam of Buliangou mine in Inner Mongolia, China, is taken as the engineering background. A mechanical model of the roadway roof structure is established to obtain an analytic formula of the key block subsidence. A three-dimensional discrete element model is established and used to verify the field measurement results. The fracture characteristics of the main roof above the F6104 transport roadway and the deformation and damage evolution law of the surrounding rock during thick coal seam mining are analyzed. The results show that because of the long-term breaking and falling of the roof rocks during extrathick coal seam mining, the F6104 transport roadway will undergo two severe mining disturbances at the locations of 10 30 m and 50 70 m ahead of the F6103 working face. During the two disturbance periods, the roadway roof displacement settles to $300 \sim 350 \mathrm{~mm}$ and $750 \sim 800 \mathrm{~mm}$, and the deformation of the solid coal wall reaches $650 \sim 700 \mathrm{~mm}$ and $1350 \sim 1450 \mathrm{~mm}$, respectively. The energy change curve of the total length of the fractured key roof is obtained, and when mining at $50 \mathrm{~m}$, the basic roof is close to its tensile strength, and the strain energy can reach the peak value of $5.2 \times 10^{4} \mathrm{~kJ}$, which easily leads to rock burst. The plastic damage zones on both sides of the roadway develop to the roof central area and eventually coalesce, and the deformation of the surrounding rock is obvious. When mining at $50 \sim 70 \mathrm{~m}$, the basic roof breaks and unloads, and elastic strain energy of $3.57 \times 10^{4} \mathrm{~kJ}$ is instantaneously released. These two dynamic disturbances are the main reasons for the instability of the roadway surrounding rock. The results clarify that the failure mechanism investigation of roadways in thick coal seam mining conditions can be effectively applied to control the stability of the roadway surrounding rock under strong mining disturbance.

\section{Introduction}

China's energy base is gradually moving west to Inner Mongolia, Xinjiang, and other western regions of China. The coal in these areas is widely distributed in extrathick seams. The single-layer thickness can be up to $10 \mathrm{~m}$ or even dozens of meters, and in China, the proportion of coal produced from these extrathick coal seams is increasing yearly [1-3]. During coal mining, the dynamic influence of the roadway depends on the lateral stress concentration, the height of the mining coal seam, the fracture strata structure, and the properties of the rock mass [4-6]. In traditional mechanized top-coal caving mining, the working face lateral roof caving is rather extensive, and the caved gangue provides support for the overlying strata, which reduces the occurrences of collapse and the lateral stress in the roof strata, thereby reducing the disturbance on the surrounding rock [7]. Fully mechanized top-coal caving mining technology has been widely used in the exploitation of extrathick coal seams in the western areas of China $[8,9]$. Due to the thickness of coal seams, a large mined-out space forms, the caving gangue can hardly fill the goaf, and the mining area accordingly increases. With the working face mining, the roofs above the roadway are covered by the overlying strata, which are supported by a cantilever beam of a certain length. In roof strata, under the action of periodic pressure, the bending stress concentration increases at a certain angle to the goaf and transfers deeply, and lateral overlying strata movement 
causes a disturbance in the adjacent roadway. Additionally, the time needed for extrathick coal seam operation is long, mining disturbances are intense, and the damage range of the roadway increases, which threatens the stability of surrounding rock [10-12]. Wang et al. [13] found that when subjected to dynamic mining activities and energy accumulation, high-stress roadways could lead to rock burst disaster. Additionally, because roadways in the extrathick coal seam are arranged in the middle of the coal seam, the roof is soft and fragile top coal, and the coal seam is weak, resulting in a low bearing strength. Due to these coal seam characteristics, roadway surrounding rock is prone to spalling and roof instability. The dynamic influence of strong mining on the roadway surrounding rock has become one of the main disasters in coal mine safety when mining is arranged in extrathick coal seams.

In this article, the failure mechanism of roadway surrounding rock under the condition of strong mining in a thick coal seam is investigated. First, a mechanical model of the main roof above the roadway is developed and used to analyze the fracture characteristics of the overlying strata. Next, a discrete numerical model is established to study the displacement variation laws and stress distribution of roadways during strong mining periods. The field measurement results are consistent with the simulation results. Finally, based on the numerical results, the damage properties and energy evolution law of roadways are obtained under thick coal seam mining. The research results of this article are of great significance for the stability control of roadway surrounding rock in strong mining conditions.

\section{Engineering Background}

The Buliangou coal mine is located in the northern region of the Zhungeer coal field of Inner Mongolia, and the main mine is the \#6 coal seam, as shown in Figure 1. The thickness of the coal seam is $16 \mathrm{~m}$, resulting in extrathick coal seam mining conditions. A longwall mining face with a height of $3.5 \mathrm{~m}$ is arranged at the bottom of the extrathick coal seam. Then, the mine pressure of the top coal above the bracket is used to break the coal into a granular form, release it from the rear of the hydraulic support, and push it out from the work face. The roadway of the Buliangou coal mine is generally affected by severe mining. The roadway deformation is sizeable, and the roof subsidence of the partial roadway is greater than $1000 \mathrm{~mm}$; thus, it is difficult to support. Repeated repair of the roadway affects the normal production of the working face, poses safety risks, and increases the amount and costs of roadway maintenance work. In this article, the F6104 transport roadway of the Buliangou coal mine is used as the engineering background, and the failure mechanism of the roadway during extrathick coal seam mining is investigated.

After an especially thick coal seam working face is mined, its strong basic roof is exposed and subsides. When the exposed area of the rock mass reaches its limit, the rock mass stress exceeds its tensile strength, and an initial fracture forms. As the working face continues to advance, the roof strata experience periodic fractures. The overburden pressure is transmitted to the surrounding coal body, causing stress to concentrate in the coal body and weaken the intensity. The fracture line of the lateral roof in extrathick coal seam top-coal caving mining, compared with conventional top-coal caving mining, is deeper in the coal wall, and under the rotation of the lateral roof, the surrounding rock will be subjected to greater compression deformation. As mining progresses, the upper strata of the roadway undergo periodic caving. The deformation and stress distribution characteristics of the surrounding rock are determined by the influence of mining on the coal seam and the caving conditions of the overlying strata.

As shown in Figure 2, the Buliangou coal mine F6103 working face coal seam has a simple structure and poor integrity. The average compressive strength of the coal seam is $9.1 \mathrm{MPa}$ and the coal easily fractures. The thicknesses of the immediate and basic roofs are $3.3 \mathrm{~m}$ and $5.3 \mathrm{~m}$, respectively, and their average compressive strengths are 21.6 $\mathrm{MPa}$ and 47.4 $\mathrm{MPa}$, respectively. Coring data suggest that the basic roof conditions are better than those of other parts of the roofs and thus play the role of key strata. The field data show that the roadway displacement during extrathick coal seam mining is 3-5 times greater than that of roadways in solid coal.

\section{Mechanical Model of Surrounding Rock Structure}

Considering the influence of mining on the working face, the relationships between the overlying rocks, the key blocks, and the surrounding rock are shown in Figure 3. The goaf roof becomes broken during the mining process and falls, and the basic roof is broken in an " $O$ - $X$ " form after the initial pressure $[14,15]$. An arc-shaped triangular rock mass is formed at the upper side of the roadway.

With continuous mining of the F6103 working face, crack transfixion produces rock mass $A$ and rock mass $B$ in the basic roof strata (Figure 4). After the basic roof of the F6104 transport roadway breaks, rock mass $A$ begins to sink, which will break the original balance with key block $B$, and key block $B$ will subside $[16,17]$. Meanwhile, the pressure on the roadway is obviously increased. The roof strata above the F6104 transport roadway fracture, rotate, and fall crosswise. The stress surrounding the roadway is redistributed. The vertical stress peak extends deeper into the coal wall, which results in the increasing deformation of the surrounding rock under the rotation of key block $B$.

$q(x)$ is the equation of the stress distribution on the $A, B$ blocks; $M_{O}$ is the rotary torque of key block $B$.

There is a distance within which the solid coal on the end of the F6103 working face should not be placed when mining, and this part of the coal seam under the weight of the partial collapse forms area $I$ in Figure 4 . The basic roof and the immediate roof gradually separate in the process of mining; they break and undergo cyclical collapse, forming the hinge structure. The amount of collapse of key block $B$ in the goaf and the amount of subsidence at the boundary of the mined side are calculated as follows [18]: 


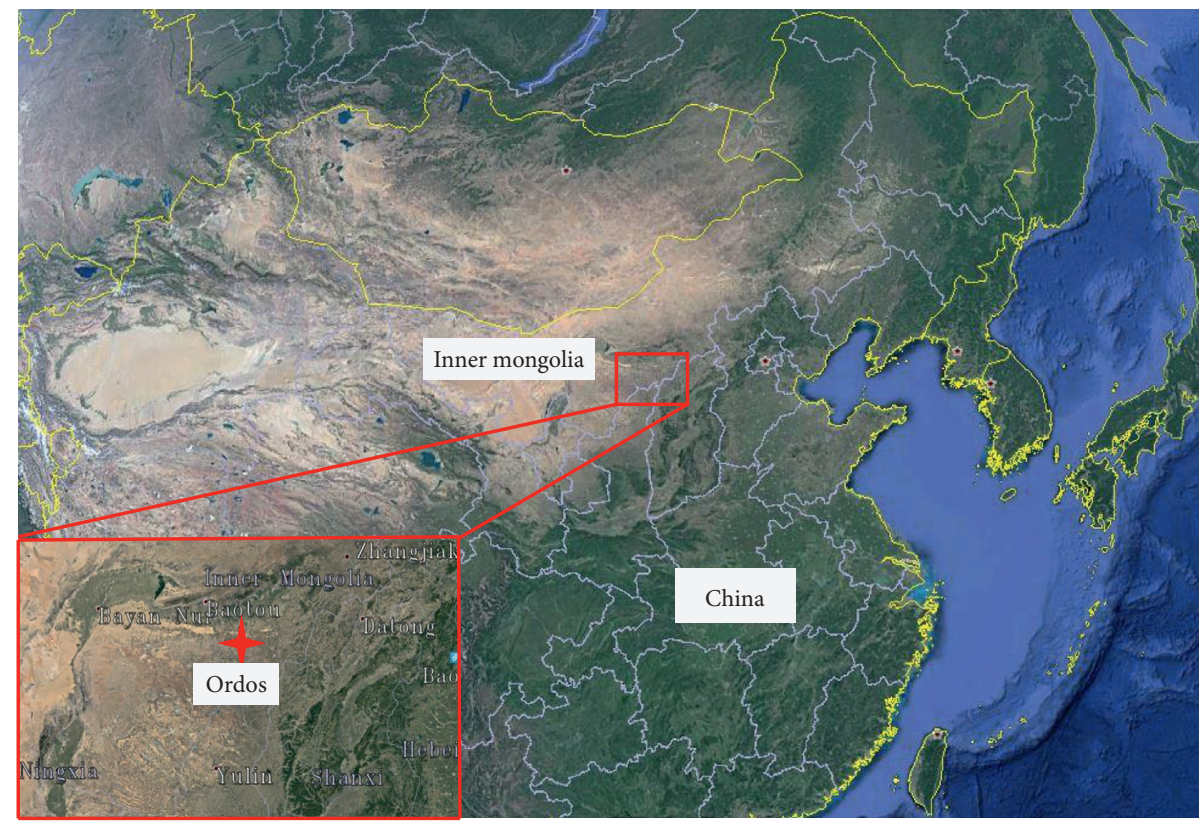

FIgURE 1: Location of Buliangou mine.

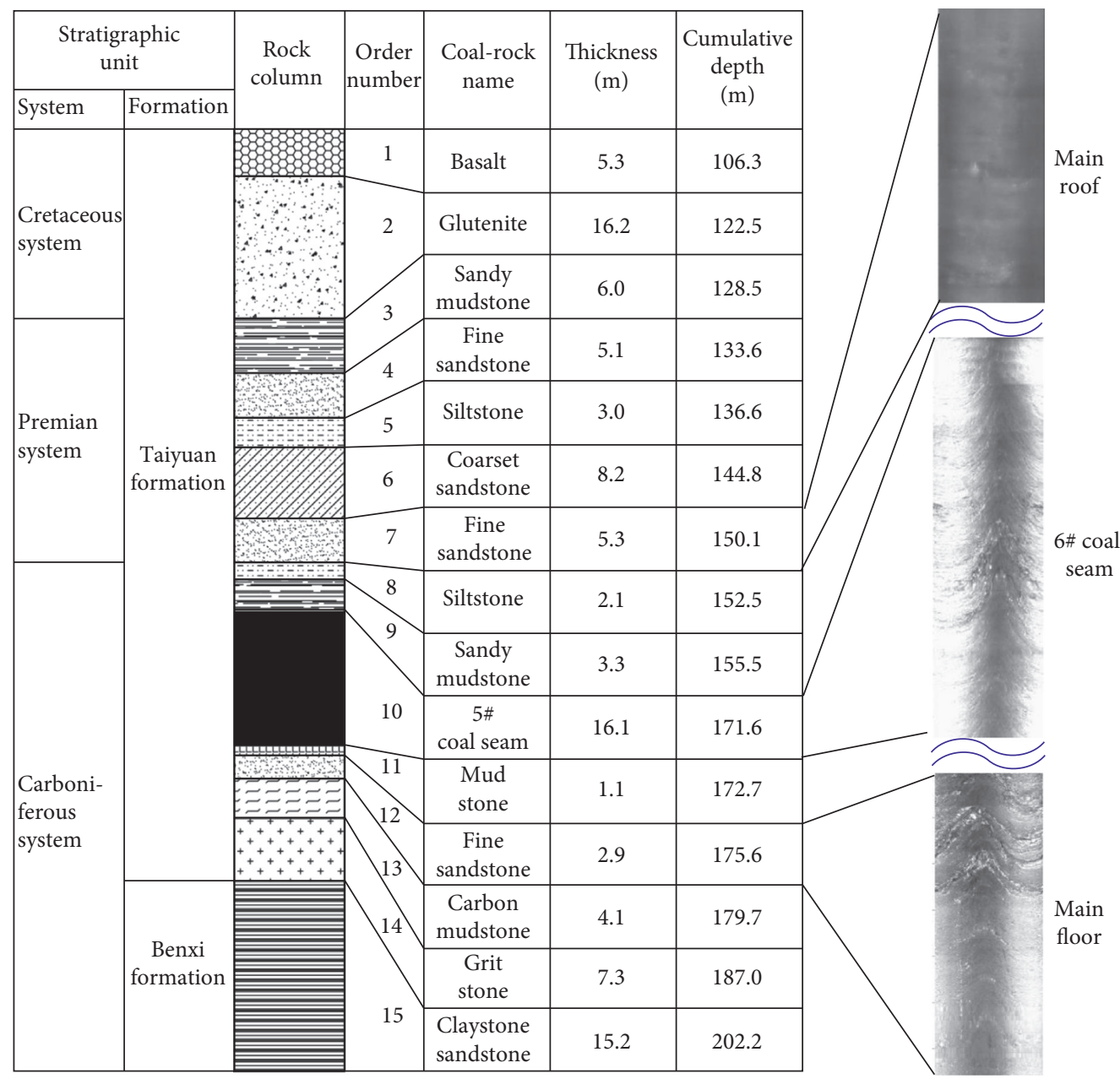

FIGURE 2: Generalized stratigraphic column. 


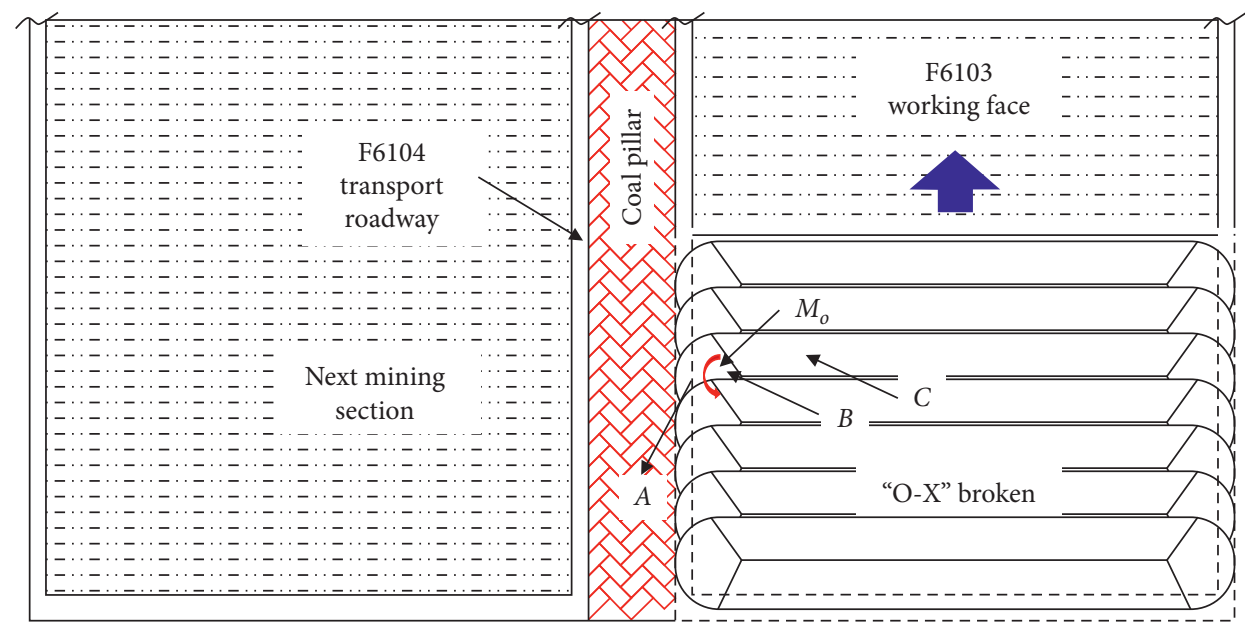

Figure 3: Plane relationship between the roadway and the overlying strata after mining.

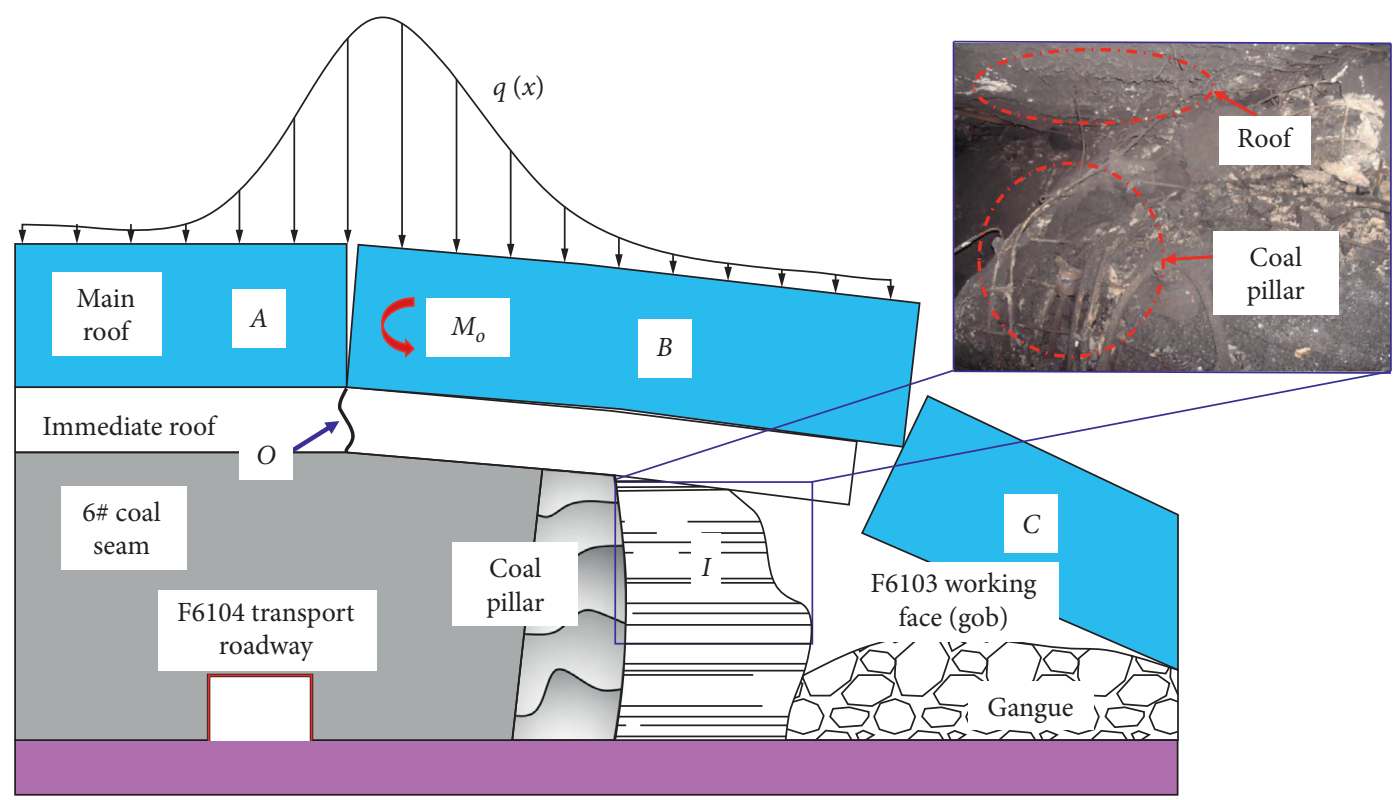

FIgURE 4: Fracture mode of roadway roof after coal mining.

$$
\begin{aligned}
& S_{1}=M-\left[T\left(K_{m}-1\right)+H_{1}\left(K_{1}-1\right)\right], \\
& S_{2}=X_{0} \cdot \sin \theta
\end{aligned}
$$

where is the coal seam mining height, $m ; T$ is the height below which working face should not be placed when mining, $m ; K_{m}$ is the expansion coefficient of the coal body, taken as $1.3 ; \eta$ is the mining recovery rate, taken as $0.8 ; K_{1}$ is the failure parameter of the overlying strata in the roadway, taken as $1.2 ; H_{1}$ is the thickness of the basic roof, $m ; X_{0}$ is the distance between the top failure location and the mining side above the roadway, $m$; $\theta$ is the rotation angle of block $B$ at the top of the roadway in contact with the filling material in the goaf area, $\theta=\arcsin \left(S_{1} / l\right) ; l$ is the length of basic roof block $B, m$.
Key block $B$ plays an important role in maintaining the roof stability of the F6104 transport roadway. Under the influence of mining, the movement of block $B$ is directly related to the stability of the surrounding rock. In the dynamic equilibrium process of the overlying strata, the surrounding rock is disturbed, and the deformation increases. As the F6103 working face is mined, blocks $A, B$, and $C$ rotate, and they sink under the action of rotary torque, causing a concentration of stress in the rock under the roadway surrounding rock, and this deformation is serious. Basic roof-load stress is $q(x)$. When key block $B$ is broken, it rotates at the $O$ point as the datum point. The cantilever beam angle is $\theta=M_{e} l / E I$, and the bending moment of the basic roof rock $W$ and the full-length strain energy $V_{\varepsilon}$ of the rock beam are as follows [19-21]: 


$$
\begin{aligned}
W & =V_{\varepsilon}=\frac{1}{2} M_{e} \theta=\frac{M_{e}^{2} l}{2 E I}, \\
V_{\varepsilon} & =\int \frac{M_{e}^{2} l}{l 2 E I},
\end{aligned}
$$

where $M_{e}$ is the bending moment of the cantilever beam structure; $E$ is the basic roof modulus of elasticity; $I$ is the inertia moment of the basic rock; and $l$ is the length of key block $B$.

When the basic roof is broken, the instantaneous angular velocity of the basic roof is 0 , the rotational acceleration is $\alpha$, and the key block $B$ centroid instantaneous acceleration is $\alpha_{B}$, where $\alpha_{B}=L / 2 \alpha$. The inertia force $F_{B}$ and the inertia torque $M_{B}$ acting on $O$ are described as follows:

$$
\begin{gathered}
F_{B}=m \alpha_{B}=m \frac{l}{2} \alpha, \\
M_{B}=J_{B} \alpha=\frac{1}{3} m l^{2} \alpha .
\end{gathered}
$$

By balancing the force in the vertical direction, the vertical stress $F_{O}$ at breakpoint $O$ is as follows:

$$
F_{O}=f_{o}+\int_{0}^{l} q(x) \mathrm{d} x+m g-\left(\frac{\alpha m l}{2}\right) .
$$

According to the principle of moment balance, the bending moment $M_{O}$ at the $O$ point is as follows [22-24]:

$$
M_{O}=f_{o} l+\int_{0}^{l} q(x) x \mathrm{~d} x+\left(\frac{m g l}{2}\right)-\left(\frac{\alpha m l^{2}}{3}\right) \text {, }
$$

where $m$ is the quality of key block $B ; J_{B}$ is the inertia moment of key block $B$; and $f_{o}$ is the vertical shear stress of key block $B$ at the goaf side.

\section{Deformation Law of Surrounding Rock in Strong Mining Disturbance Conditions}

4.1. Model Establishment. To explore the influence of strong mining disturbance on the roadway in the \#6 coal seam of the Buliangou coal mine, the F6104 transport roadway was selected, and a three-dimensional model was established, by adopting discrete element software (3DEC), as shown in Figure 5.

The model size is $141 \mathrm{~m} \times 100 \mathrm{~m} \times 60 \mathrm{~m}$; the mining thickness is $16 \mathrm{~m}$; the design mining height is $3.5 \mathrm{~m}$; the topcoal caving mining height is $12.5 \mathrm{~m}$. The equivalent load calculation formula set at the upper boundary of the model is $q=\gamma \times h$, and $h$ is the height from the top of the model to the unmodeled part of the ground. The lateral displacement of the model is limited by the displacement boundary, and the vertical movement is restricted by the bottom surface. The Mohr-Coulomb strength criterion is used to judge the yielding of the coal and rock mass [25-27]:

$$
f_{s}=\sigma_{1}-\sigma_{3}\left(\frac{1+\sin \varphi}{1-\sin \varphi}\right)+2 C\left(\sqrt{\frac{1+\sin \varphi}{1-\sin \varphi}}\right)
$$

where $\sigma_{1}$ and $\sigma_{3}$ are the maximum and minimum principal stresses, respectively. $C$ and $\varphi$ are the bonding force and frictional angle of the rock, respectively. When $f_{s}>0$, the material experiences shear failure. The Mohr-Coulomb failure criterion can comprehensively reflect the strength characteristics of rock, and this criterion is widely applied in underground engineering. When the rock reaches the yield limit, plastic flow is generated. Table 1 shows the mechanical parameters of the rock mass. These microparameters of block contact faces in the 3DEC model were obtained from the same size of uniaxial compression tests when the simulated compression test results were consistent with the physical test results. The joint mechanical parameters of rock mass are listed in Table 2.

4.2. The Fracture Characteristics of the Roof above the Roadway during Mining. The vertical displacement and fracture characteristics surrounding the F6104 transport roadway are shown in Figure 6. Extrathick coal seam mining increases the falling height of the roof. The range of the top roof affected by mining disturbances increases, which leads to the enlargement of the range of the stress influence area.

After mining at $0 \sim 30 \mathrm{~m}$, the roof strata above the F6104 transport roadway are in the initial state of the cantilever on the goaf side. With continued mining at $30 \sim 50 \mathrm{~m}$, the deformation and deflection of the basic roof greatly increase, and the length of the cantilever reaches the breakage limit. When mining at 50 70 m, severe fracture and subsidence occur on the goaf side. The breaking position of the roof penetrates deeply into the coal pillar, which drastically reverses and sinks near the breaking point. Dynamic pressure load transfer occurs on the adjacent F6104 section of the transport roadway, resulting in obvious deformation and damage to the surrounding rock.

As the goaf roof cannot cut along the solid coal, it will have a certain collapse angle. The larger the thickness of the mining area is, the greater the space for collapse is; furthermore, the height and length of the lateral roof are also greater on the goaf side. For the setting test line of block $B$, the coal-pillar side end, the midpoint, and the goaf side-end monitoring point are points $a, b$, and $c$, respectively, and the vertical stress and vertical displacement curves are shown in Figure 7. Due to mining effects on the F6104 roadway, more stress from the overburdened rock is transferred to the top of the roof on the goaf side, leading to increased stress concentrations of the coal pillar in the roadway and the stability influence on the adjacent F6104 transport roadway.

When mining at $0 \sim 30 \mathrm{~m}$, block $B$ is bent and sinking, and the $O$ point is used as the rotation reference point to generate a large stress concentration and reach the peak value. The vertical displacement of the three monitoring points gradually increases. When mining at $30 \sim 50 \mathrm{~m}$, rock block $B$ breaks at point $O$, the stress release at monitoring point a is sharply reduced, and the vertical displacement tends to be stable. The edge of the coal pillar experiences plastic damage, and the vertical displacement greatly increases at points $b$ and $c$. When mining at $50 \sim 70 \mathrm{~m}$, the stress 


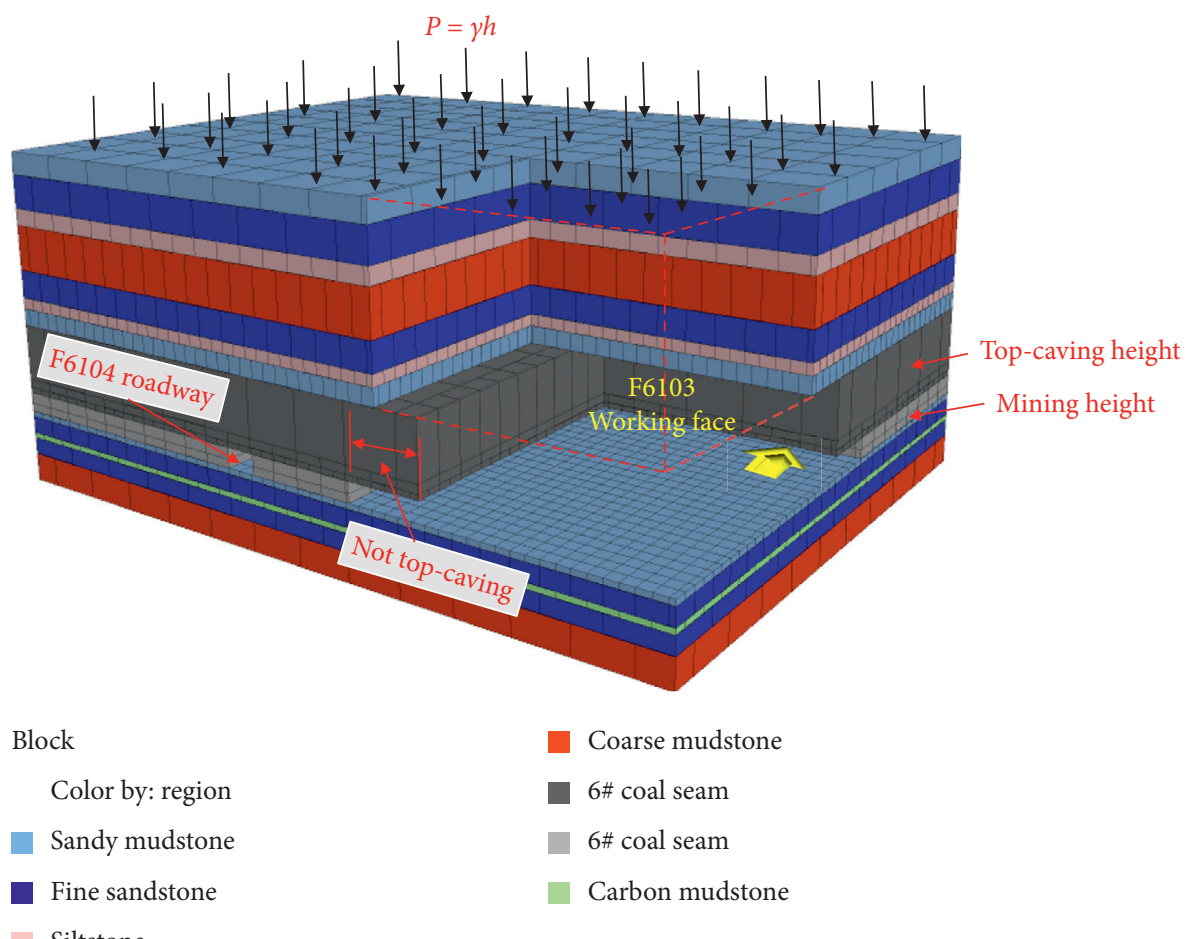

Figure 5: 3DEC numerical model.

TABLE 1: The mechanical properties of the rock mass.

\begin{tabular}{lcccccc}
\hline Parameters & Bulk $(\mathrm{GPa})$ & Shear modulus $(\mathrm{GPa})$ & Tension $(\mathrm{MPa})$ & Cohesion $(\mathrm{MPa})$ & Friction $\left.^{\circ}\right)$ & Density $^{\left(\mathrm{kg} \cdot \mathrm{m}^{-3}\right)}$ \\
\hline Sand mudstone & 6.5 & 8.6 & 2.6 & 1.2 & 32 & 2600 \\
6\# coal seam & 1.5 & 2.0 & 0.9 & 1.7 & 1.4 & 24 \\
Mudstone & 12 & 8.6 & 4.2 & 1.45 & 30 & 2450 \\
Fine sandstone & 36 & 12.6 & 2.1 & 1.0 & 31.5 & 2200 \\
Silestone & 25 & 4.6 & & 2600 & 2500 \\
\hline
\end{tabular}

TABLE 2: Joint mechanical parameters of rock mass.

\begin{tabular}{|c|c|c|c|c|c|}
\hline Joint property & Sand mudstone & 6\# coal seam & Mudstone & Fine sandstone & Silestone \\
\hline Normal stiffness $(\mathrm{GPa} / \mathrm{m})$ & 134.2 & 86.5 & 102.4 & 276.4 & 186.1 \\
\hline Shear stiffness $(\mathrm{GPa} / \mathrm{m})$ & 53.7 & 34.5 & 40.8 & 110.5 & 72.6 \\
\hline Cohesion (MPa) & 1.1 & 0.5 & 1.0 & 1.3 & 0.9 \\
\hline Tension $(\mathrm{MPa})$ & 2.6 & 0.9 & 1.7 & 4.2 & 2.1 \\
\hline Friction angle $\left({ }^{\circ}\right)$ & 29 & 25 & 28 & 31 & 32 \\
\hline
\end{tabular}

at points $b$ and $c$ gradually reaches the peak, and the vertical displacement dramatically increases. When mining at $50 \sim 70 \mathrm{~m}$, the vertical displacement and vertical stress of points $a$ and $b$ decrease and stabilize. The range of the plastic damage of the coal-pillar edge is further enlarged at point $c$, and the vertical displacement varies insignificantly.

The movement and structural instability of the roof in the F6104 transport roadway results in increased resistance of the hydraulic supports at the end of the F6103 working face. The safety valve frequently opens (opening rate of approximately $67 \% \sim 34 \%$ ), showing that a large area of the overlying rock is broken on the mining side. With periodic pressure, the roof often experiences severe sinking and rib spalling. The section in which coal is not placed at the end of the working face includes hydraulic supports\#93-98, as shown in Figure 8 with the work-resistance curve of hydraulic support\#95.

When the basic roof of a coal seam becomes bent and broken, this deformation is accompanied by a strong impact load, and the initial and periodic pressure changes become more severe. The distance to which the hydraulic support changes the pressure in the section where coal is not placed at the F6103 face is $28.6-33.6 \mathrm{~m}$. The dynamic load factor is 2.1-2.9, with an average of 2.5, illustrating the strong dynamic load caused by the fracturing of the basic roof above the roadway. At the same time, the top roof rock is broken, 


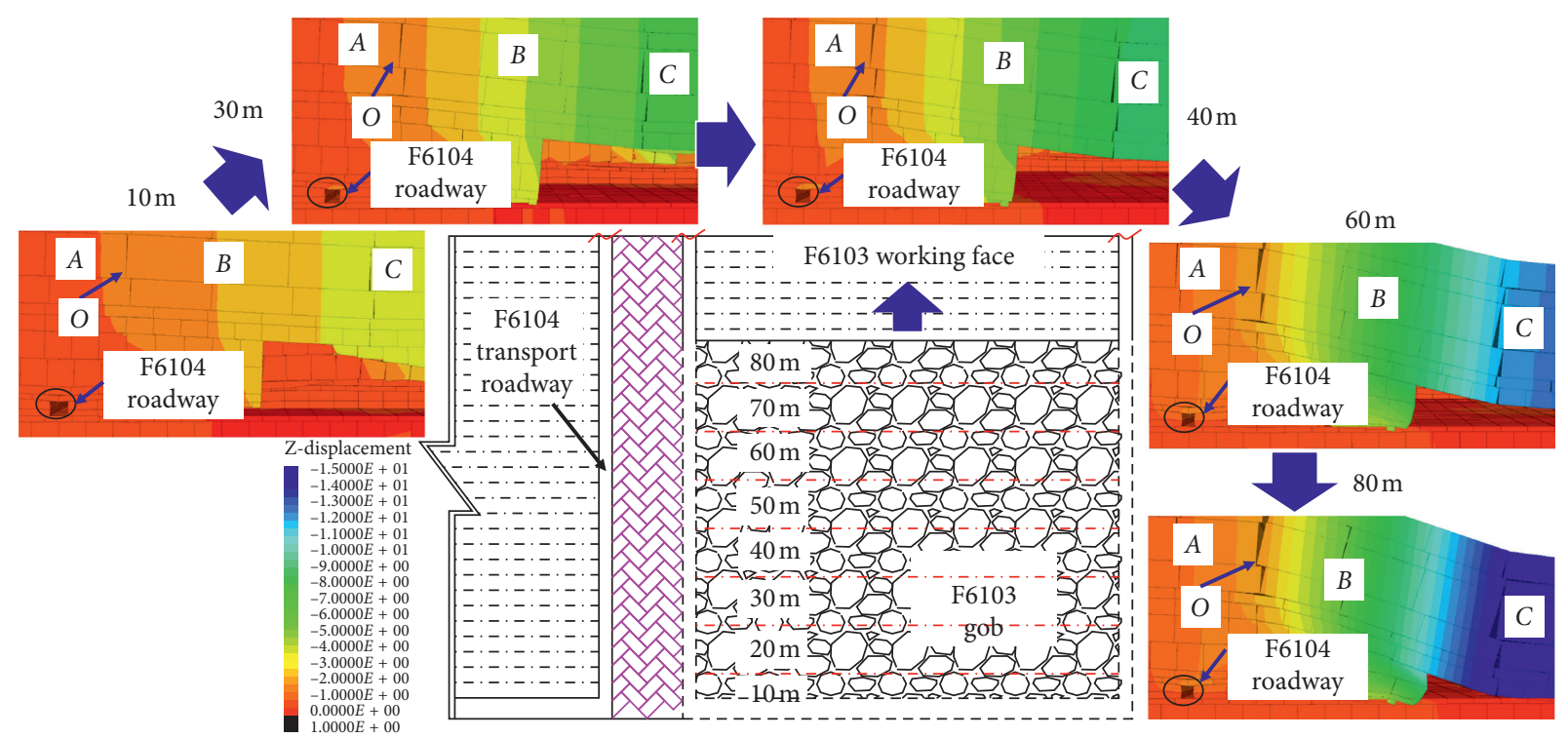

Figure 6: Fracture characteristics and vertical displacement of the roadway under the influence of mining.

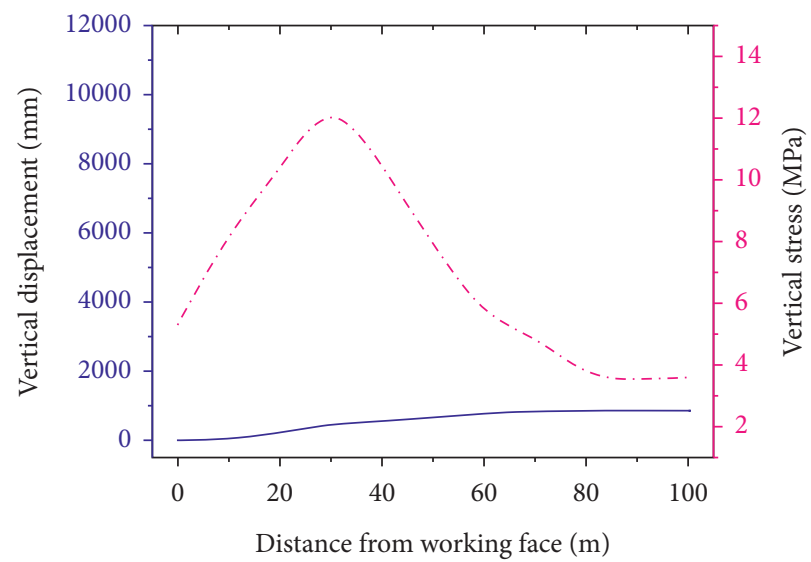

- Vertical displacement -... Vertical stress

(a)

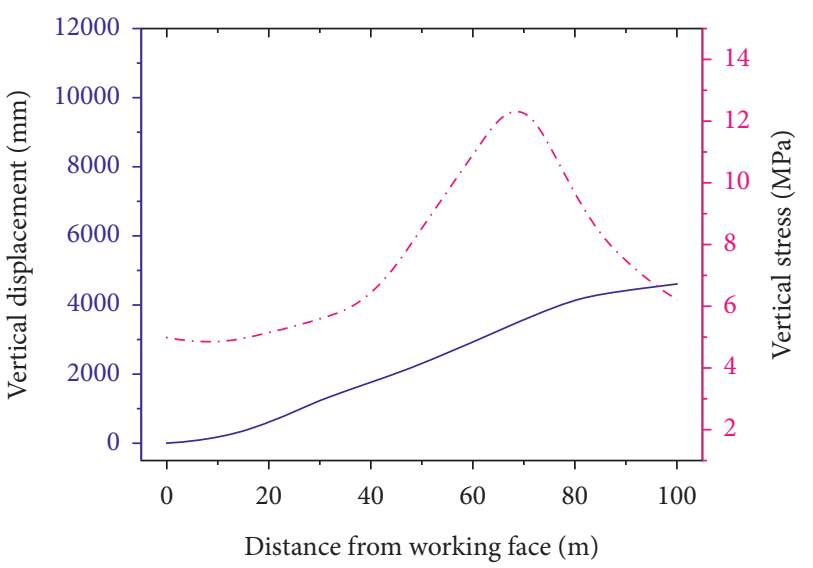

— Vertical displacement

-... Vertical stress

(b)

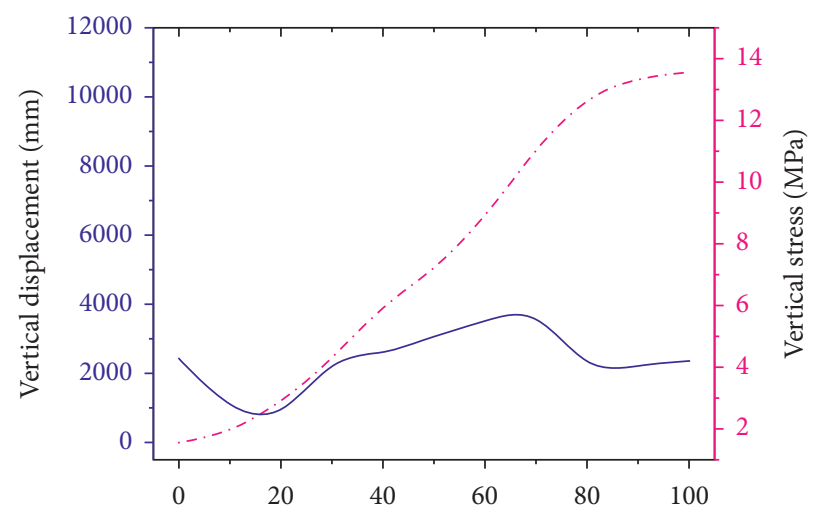

Distance from working face $(\mathrm{m})$

— Vertical displacement

-... Vertical stress

(c)

FIGURE 7: The vertical displacement and the vertical stress curve of the monitoring points. (a) Monitoring curve of " $a$ " point. (b) Monitoring curve of " $b$ " point. (c) Monitoring curve of " $c$ " point. 


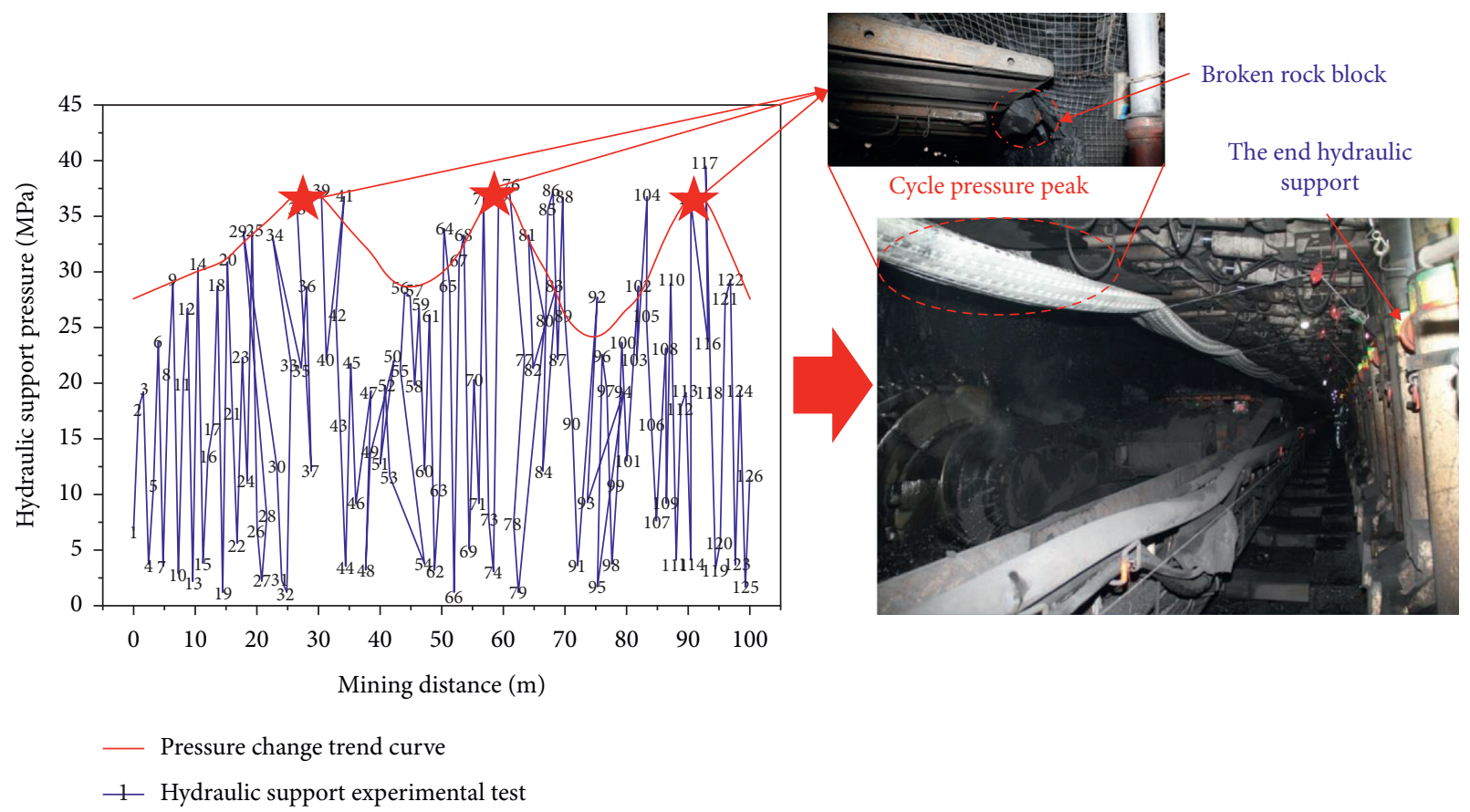

FIgURE 8: Resistance curve of \#95 hydraulic support in the roadway.

and the falling rock blocks are large. The caving rock is $15-30 \mathrm{~m}$ in length, which has a large impact and destructive effect on the end bracket.

4.3. Deformation Law of Surrounding Rock. When the F6103 face was mined, the F6104 transport roadway experienced several mining disturbances, showing severe mine pressure failure characteristics. The depth of the coal-wall rib spalling reached more than $800 \mathrm{~mm}$, and the two drums reached a maximum amount of more than $1100 \mathrm{~mm}$, which was especially serious at the coal-pillar rib. The roadway roof subsidence was significant, the local steel roof was deformed, and the bolt (cable) was broken, as shown in Figure 9. The displacement monitoring points were arranged on the surface of the roadway in the field and the three-dimensional model; a comparison of the roadway displacement is shown in Figure 10.

The displacements of the roof, floor, and two sides of the roadway are different. The displacement of the coal wall is obviously smaller than that on the coal-pillar side, which shows that after mining, the overburden stress transfers to the surrounding rock areas, resulting in a significant increase in coal-wall displacement. The influence of mining activities on the working face subsidence varies from large to small and ultimately tends to be stable.

When mining the F6103 working face at $0 \sim 35 \mathrm{~m}$, due to the bending and sinking of the basic roof, the slope of surface deformation of the F6104 roadway's roof and pillar side is greater than that of other areas, and the deformation is more obvious. The settlement at the surface is $400 \sim 450 \mathrm{~mm}$, and that at the side of the coal pillar reaches $800 \sim 850 \mathrm{~mm}$. When mining at $35 \sim 55 \mathrm{~m}$, due to the clamping action of the upper and lower coal rock masses, the rock becomes temporarily stable, the slope of the surface displacement curve is small, and the deformation tends to be stable. When mining at $55 \sim 75 \mathrm{~m}$, the hanging space of the basic roof constantly increases, and the overburden pressure is transmitted to the lower cover layer, which leads to the rotation of the broken rock strata in the goaf. Due to the large mined-out space produced by extrathick coal seam mining, the slope of the displacement curve abruptly increases for long-term dynamic loading action on the F6104 transport roadway and the pillar. The settlement at the surface is $650 \sim 700 \mathrm{~mm}$, and that at the side of the coal pillar reaches 1350 1450 mm. When mining reaches $75 \mathrm{~m}$, the overburden strata compact crosswise, and the displacement stabilizes once again. Only when mining at $0 \sim 30 \mathrm{~m}$ under the influence of periodic pressure, the slope of the displacement curve is small, with a maximum deformation of $400 \sim 425 \mathrm{~mm}$; this displacement curve is more stable than that when mining at $30 \mathrm{~m}$, for which the final deformation is $450 \sim 475 \mathrm{~mm}$.

\section{Plastic Damage and Energy Evolution Law of Roadway}

5.1. Analysis of Plastic Damage for Roadway Surrounding Rock. As the extrathick coal seam is mined at the F6103 working face, the F6104 transport roadway needs to be maintained for a long time. The strength of the roadway rock is badly degraded, and the roof's contraction and sinking are considerable. At the same time, the compressive load is also increasing, and the lateral shear expansion will significantly increase. Figure 11 shows the plastic damage process of the coal and rock mass around the F6104 transport roadway and the F6103 working face. The light blue area indicates the area of coal with original stress state, the pink area indicates the area of coal with shear failure, the blue area is the 


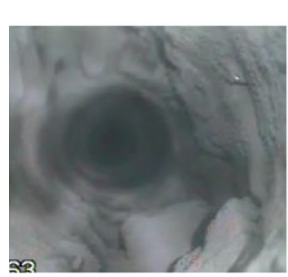

Broken section

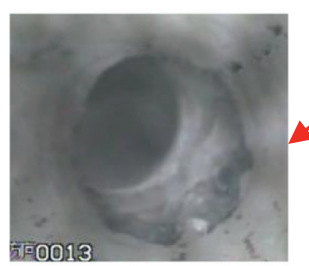

Separation layer

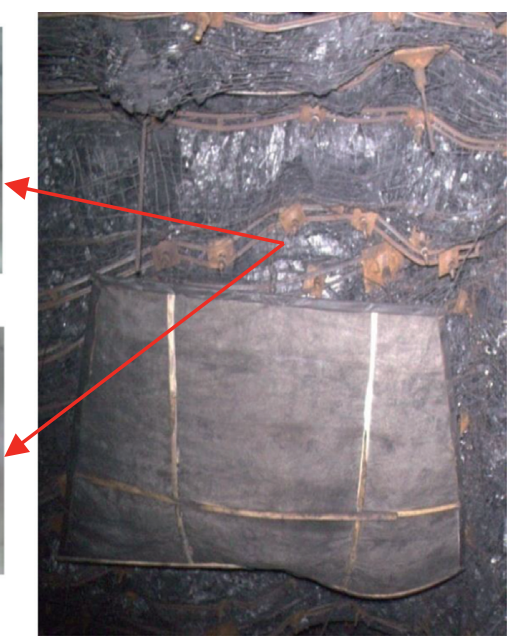

(a)

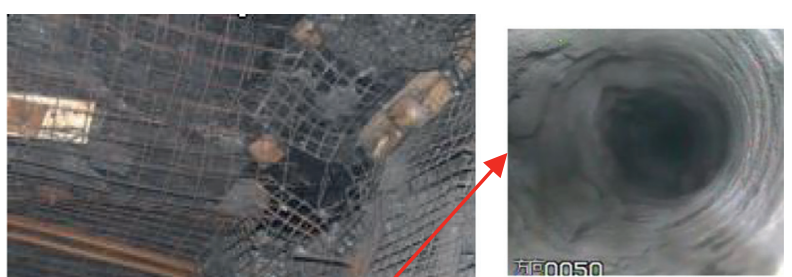

Fracture development

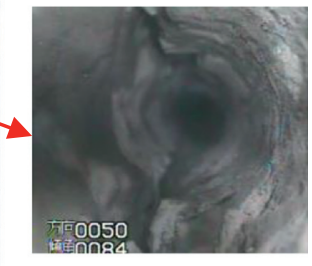

Fracture coalescence

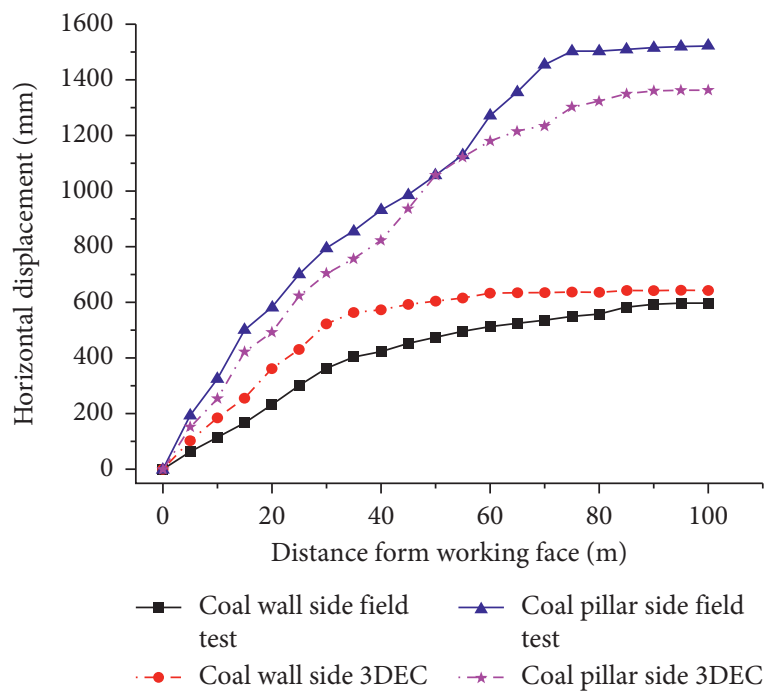

(b)

FIGURE 10: Displacement comparison of the roadway surrounding rock. (a) Roof subsidence curve. (b) Displacement curve of roadway two sides.

FIgURE 9: Deformation failure of the roadway.

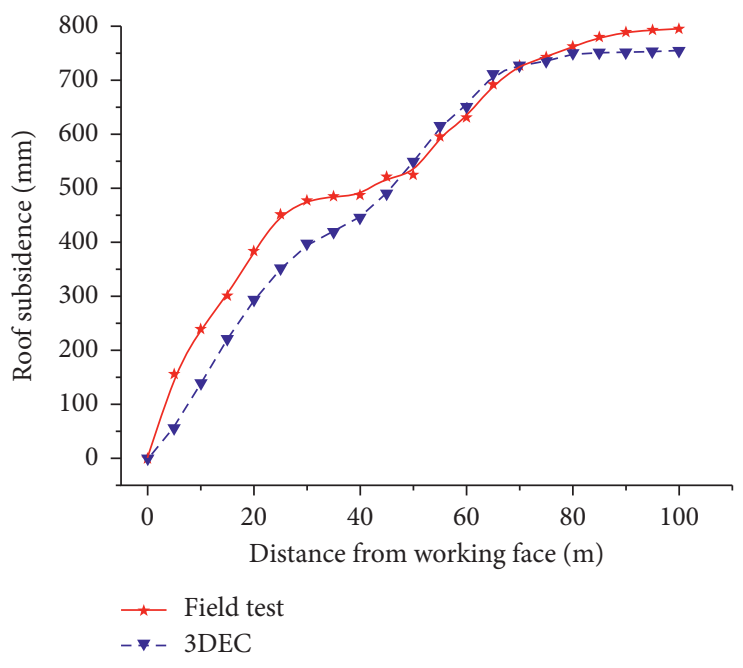

(a)
Block

Color by: state

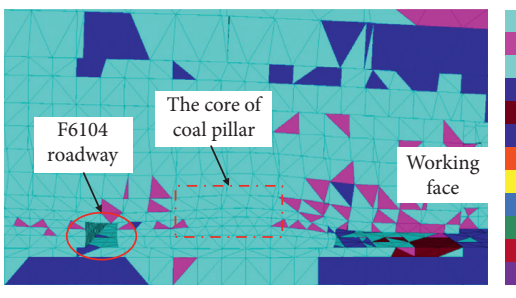

(a)
Shear- $n$ shear- $p$

Tension- $n$ shear $-p$ tension $-p$ Shear- $p$

Tension- $n$ shear- $p$ tension- $p$

Shear $-p$ shear $-p$
Tension $-n$ shear $-p$

Tension- $p$

Tension- $n$ tension- $p$

Tension $-n$ shear $-p$

Shear- $n$ tension- $p$

Tension- $n$ (b) 


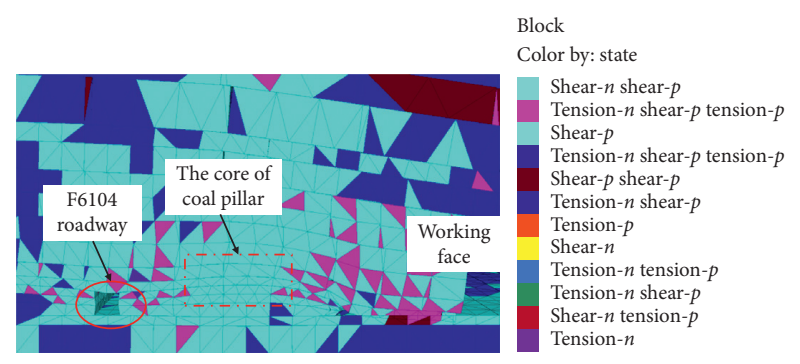

(c)

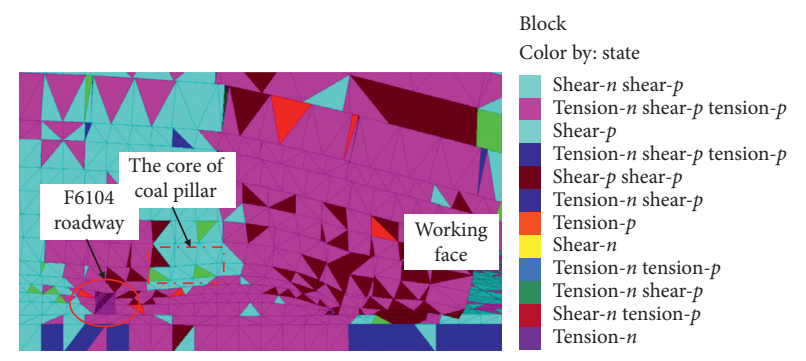

(d)

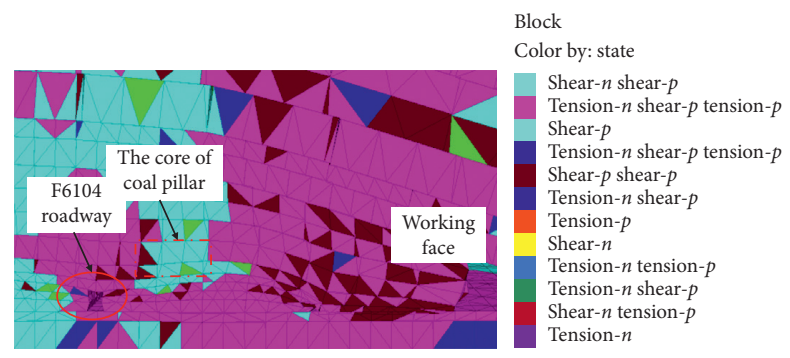

(e)

FIGURE 11: Evolution process of the plastic zone in roadway surrounding rock in mining conditions. (a) $10 \mathrm{~m}$. (b) $30 \mathrm{~m}$. (c) $50 \mathrm{~m}$. (d) $70 \mathrm{~m}$. (e) $90 \mathrm{~m}$.

tensile-failure coal rock mass, and the brown area indicates the area with compression failure.

The roof-pillar-floor is a part of the rock structure and mining will cause stress changes in the coal. The edge of the coal pillar is the first part of the pillar to enter the yield damage state, creating a large area of breaking and falling, leading to a decrease in the effective bearing area and an increase in the stress concentration coefficient and further expanding the scope of the coal-pillar yield zone. When the stress in the core area of the coal pillar is reduced to the limit equilibrium state, it can easily induce the sudden destabilization of the surrounding rock. When mining at $10 \mathrm{~m}$, the rock mass is in the original stress state, and only the partial plastic area of the surrounding rock is disturbed by the mining effect. Mining at $30 \mathrm{~m}$ and $50 \mathrm{~m}$, the edge pillar of the mined area is the boundary support point of the broken roof, and it is subjected to the transfer pressure formed by the bending and breaking of the basic roof rock. A stress concentration area arises in the coal pillar, and a damage zone develops from the roadway and goaf to the coal pillar. When mining at $70 \mathrm{~m}$, the coal-pillar damage zones mutually interact. The roadway roof is destroyed by shearing and tension, most of which is a shear failure. The failure regions on the roadway ribs are serious. When mining at $90 \mathrm{~m}$, the plastic region tends to be stable.

The lateral abutment pressure is disturbed by the mining of the working face, which causes a change in the load supported by the coal pillar, as shown in Figure 12. When the lateral abutment pressure increases, the coal-pillar edge begins to fall, while the pillar of the central part of the stress concentration factor begins to rise dramatically. The coal pillar develops fractures and even breaks, and its stability is difficult to maintain. At the same time, the pillar support function is weakened, and the roadway span and suspension roof distance are enlarged, leading to the instability of the coal and rock mass around the roadway.

When mining the F6103 working face at $10 \mathrm{~m}$, the F6104 roadway is not affected by the mining disturbances induced around the surrounding rock. The basic roof bears a load similar to a uniformly distributed load, and the surrounding rock initially remains stable. With the increase in mining, at $30 \sim 50 \mathrm{~m}$ behind the working face, the plastic range extends to the center from the two sides of the coal pillar, and the stress of the coal pillar greatly fluctuates, gradually destabilizing. The stress distribution of the coal pillar is unimodal. At 50 70 $\mathrm{m}$ behind the working face, due to the large space formed by the extrathick coal seam mining, the spatial scale of the movement and the destruction of the overlying strata is long, and the abutment pressure is strong, easily damaging the coal rock mass around the F6104 transport roadway. The stress and the strength of rock decrease, the crack expansion increases, and significant plastic slippage occurs. Both sides of the coal pillar exhibit a plastic damage zone with a certain width, and the boundary bearing capacity is reduced sharply. Farther than $70 \mathrm{~m}$ behind the working face, the coal-pillar stress and rock mass movement basically become stable, and the plastic zone of the coal-pillar stabilizes to its largest range.

5.2. Energy Evolution Law of Roadway Roof under the Dynamic Load. Due to mining, key block $B$ increases the bending moment of the rock beam and stores more elastic strain energy under the rotation action of the overlying strata. When the strain energy stored in the rock mass storage is released in an instant, a strong mining disturbance is caused to the roadway. Therefore, roof collapse and rock burst disasters easily occur, as shown in Figure 13. The stress 


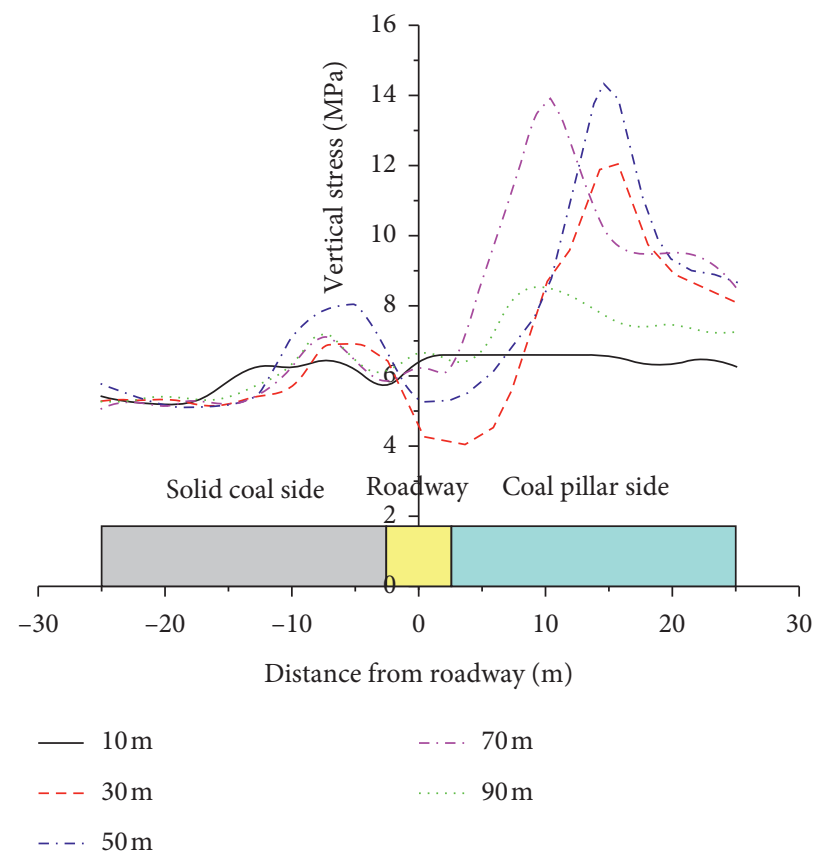

FIGURE 12: Lateral support stress distribution of roadway.

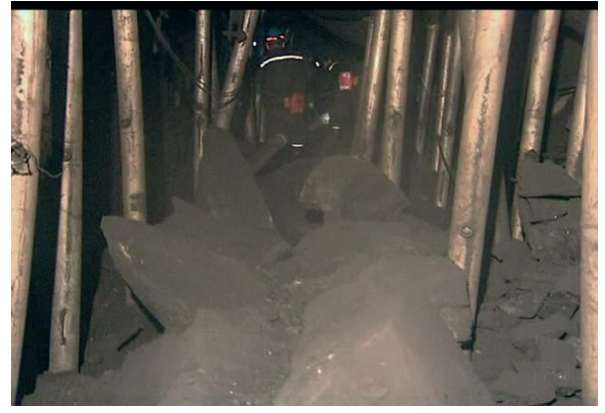

(a)

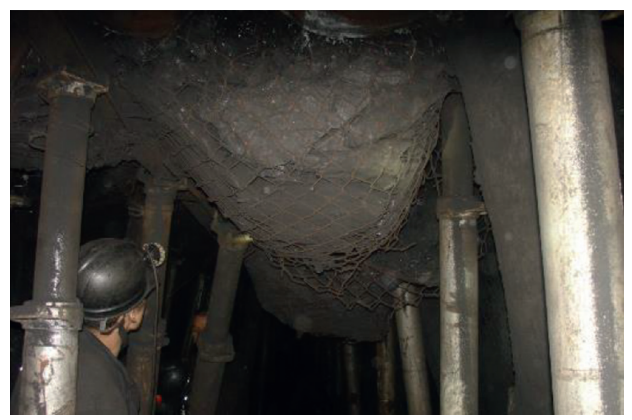

(b)

FIgURE 13: Roadway failure caused by release of strain energy. (a) Rock burst. (b) Roof collapse.

distribution is nonuniform, and it will change under the influence of mining. The stress distributions at $30 \mathrm{~m}, 50 \mathrm{~m}$, $70 \mathrm{~m}$, and $90 \mathrm{~m}$ for block $B$ at the rear of the working face are fitted into equation (7), and the parameters are shown in Table 3.

$$
q(x)=B_{1} x^{4}+B_{2} x^{3}+B_{3} x^{2}+B_{4} x+C .
$$

The function principle suggests that the strain energy $V_{\varepsilon}$ of the basic roof can be equal to the work done $W$ by an external force; that is, $V_{\varepsilon}=W$. The bending moment equation is as follows [28-30]:

$$
M(x)=\int_{l} q(x) \cdot x \mathrm{~d} x .
$$

Formula (7) is brought into formulas (2), (3), and (8), and the energy distribution curves of basic roof block $B$ at $30 \mathrm{~m}, 50 \mathrm{~m}, 70 \mathrm{~m}$, and $90 \mathrm{~m}$, behind the working face are obtained, as shown in Figure 14.
The elastic strain energy of key block $B$ on the goaf side of the F6104 transport roadway increases continuously and reaches the maximum of $5.2 \times 10^{4} \mathrm{~kJ}$. Meanwhile, the rock mass surrounding the F6104 transport roadway is in the elastic-plastic equilibrium state. When mining at $50 \sim 70 \mathrm{~m}$, key block $B$ breaks and unloads, and the coal and rock mass deforms more, accumulating the strain energy of $3.57 \times 10^{4} \mathrm{~kJ}$. When mining farther than $70 \mathrm{~m}$, the residual strain energy of the coal and rock mass around the roadway tends to be stable, at $1.3 \times 10^{4} \sim 1.63 \times 10^{4} \mathrm{~kJ}$.

Basic roof rock $B$ undergoes an angular acceleration $\alpha$, which produces a large inertia force and moment of inertia, leading to local coal rock mass deformation and failure. While mining at 50 70 $\mathrm{m}$, the high strain energy of the basic roof is suddenly released, and the instability of the overlying rock structure leads to strong mine pressure on the F6104 transport roadway. According to the balance principle, all the main, binding, and inertial forces act on the rock beam and are composed of the balance-force system. Using 
TABLE 3: Stress distribution curve-fitting parameters.

\begin{tabular}{lccccr}
\hline Mining distance $(\mathrm{m})$ & $B_{1}$ & $B_{2}$ & $B_{3}$ & $B_{4}$ & $C$ \\
\hline 30 & $2.35 \times 10^{-4}$ & $-1.4 \times 10^{-2}$ & 0.233 & -0.628 & 4.197 \\
50 & $2.66 \times 10^{-4}$ & $-1.6 \times 10^{-2}$ & 0.273 & -0.857 & 5.149 \\
70 & $1.6 \times 10^{-8}$ & $-5.19 \times 10^{-4}$ & $-3.34 \times 10^{-2}$ & 0.582 & 0.928 \\
90 & $5.56 \times 10^{-5}$ & $-3.08 \times 10^{-3}$ & $4.28 \times 10^{-2}$ & $-1.70 \times 10^{-2}$ & 5.41 \\
\hline
\end{tabular}

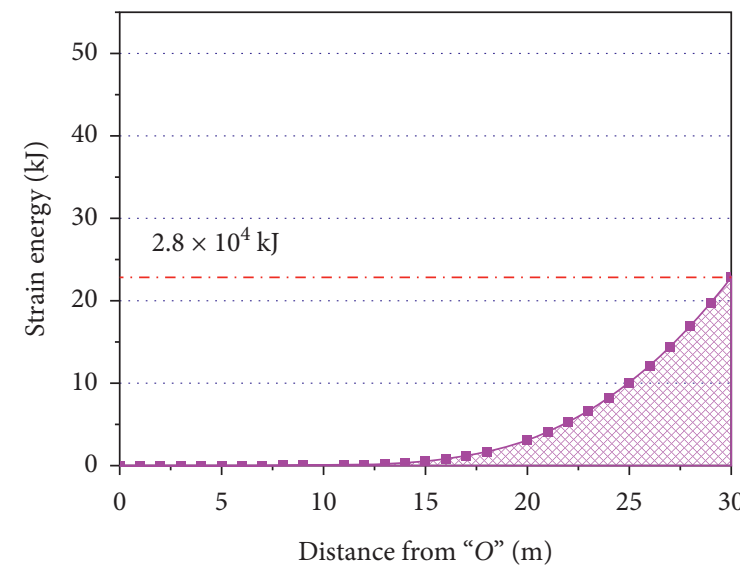

(a)

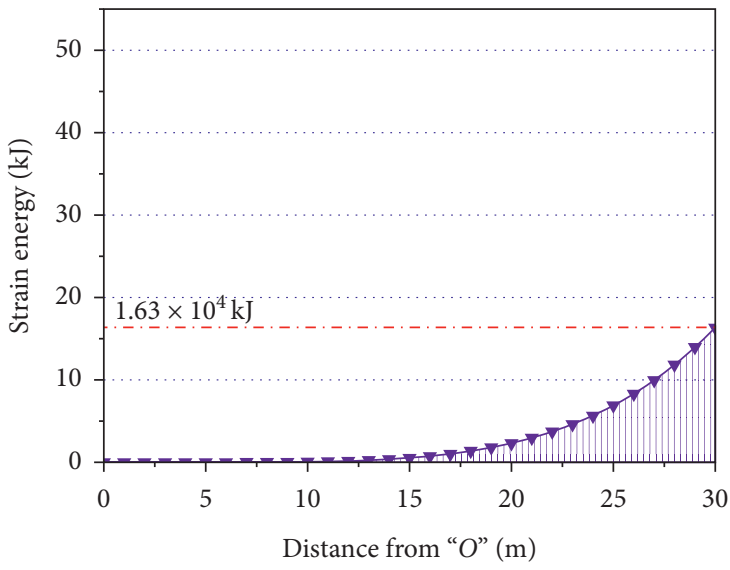

(c)

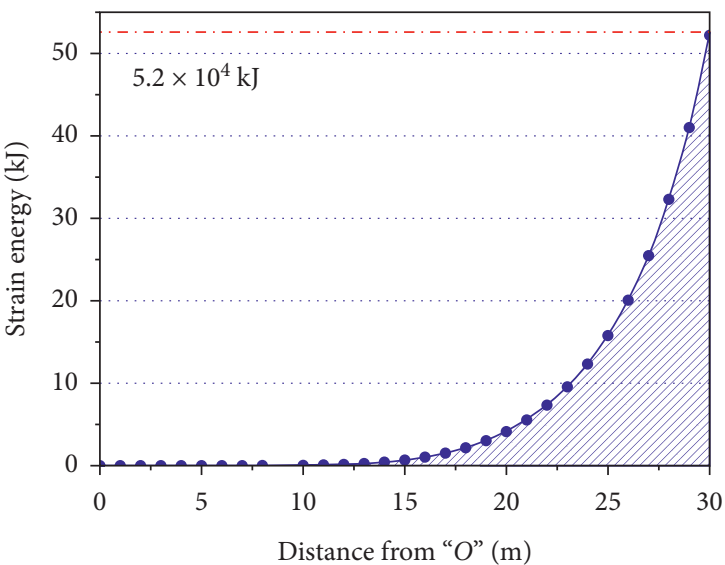

(b)

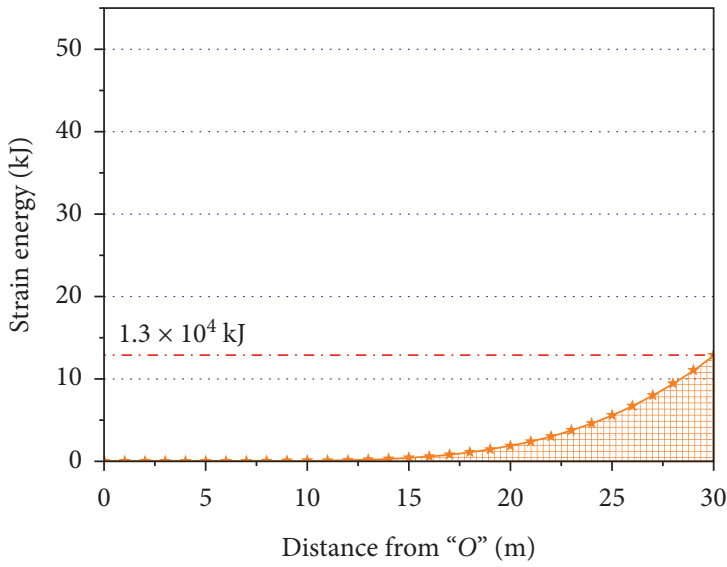

(d)

Figure 14: Elastic strain energy curve of key rock mass B.(a) $30 \mathrm{~m}$. (b) $50 \mathrm{~m}$. (c) $70 \mathrm{~m}$. (d) $90 \mathrm{~m}$.

formulas (4) (7), the fracture moment of basic roof rock mass $B$, the additional force $\Delta F_{O}$ and the additional moment of inertia $\Delta M_{O}$ caused by the break are as follows:

$$
\begin{aligned}
\Delta F_{O} & =\frac{m \alpha l}{2}, \\
\Delta M_{O} & =\frac{m \alpha l^{2}}{3} .
\end{aligned}
$$

The primary cause of the second severe roadway disturbance is the dynamic load-bearing action caused by the breaking of the basic roof in an extrathick coal seam when the mining distance is greater than the periodic breaking distance. At the end of the process of mining disturbance, key block $B$ is compacted, and the roadway surrounding rock is in a state of plastic yield.

\section{Conclusions}

Taking the Buliangou mine, Inner Mongolia, China, as the engineering background, the failure mechanism of a roadway surrounding rock under the strong disturbance of mining a thick coal seam was investigated through theoretical analysis, numerical simulation, and field measurement. This article includes the following conclusions:

(1) The breaking characteristics and the movement rules of the key roof above the roadway were studied by establishing a mechanical model of the roadway roof in extrathick coal seam mining. The bending moment of the key roof, the rock beam's length-strain energy expression, and the roles of the key block's fault-point inertia force and inertia moment were obtained. 
(2) Compared to the mining of thinner coal seams, in extrathick coal seam mining, the roof's caving height is increased, and the range of disturbance is increased above the coal seam. In the field and simulation results, when mining at $0 \sim 30 \mathrm{~m}$, the roof s cantilever beam of the roadway's goaf side reaches the breaking limit from the initial pressure, and the stress concentration factor is large. The displacement is asymmetric on the two sides of the roadway. When mining at 50 70 m, key rock block $B$ fractures and subsides. The broken position is deep inside the coal pillar, taking $O$ as the basic point of the reverse subsidence, forming a severe dynamic load, which is transferred to the F6104 transport roadway. The roadway roof is partially destroyed by shearing and tensile damage, most of which is a shear failure. When mining at $90 \mathrm{~m}$, the plastic zone no longer extends, and the stress and deformation of the surrounding rock are stable.

(3) When mining at $0 \sim 30 \mathrm{~m}$, the basic roof of the roadway deforms and continues to accumulate elastic strain energy to $2.8 \times 10^{4} \mathrm{~kJ}$. When mining at $30 \sim 50 \mathrm{~m}$, the elastic strain energy of the basic roof reaches $5.2 \times 10^{4} \mathrm{~kJ}$. The bearing capacity of the coal and rock mass around the roadway sharply decreases. When mining at $50 \sim 70 \mathrm{~m}$, the basic roof rock instantly unloads and releases elastic strain energy at $3.57 \times 10^{4} \mathrm{~kJ}$. At that time, the roadway is subjected to a second severe disturbance, which easily leads to roadway instability.

\section{Data Availability}

The data used to support the findings of this study are included within the article.

\section{Conflicts of Interest}

The authors declare that they have no conflicts of interest.

\section{Acknowledgments}

This study was supported by the National Natural Science Foundation of China (No. 27183004).

\section{References}

[1] Z. Zhou, Y. Zhao, W. Cao, L. Chen, and J. Zhou, "Dynamic response of pillar workings induced by sudden pillar recovery," Rock Mechanics and Rock Engineering, vol. 51, no. 10, pp. 3075-3090, 2018.

[2] M. Marschalko, I. Yilmaz, M. Bednárik, K. Kubečka, T. Bouchal, and J. Závada, "Subsidence map of underground mining influence for urban planning: an example from the Czech republic," Quarterly Journal of Engineering Geology and Hydrogeology, vol. 45, no. 2, pp. 231-241, 2012.

[3] H. W. Zhang, Z. J. Zhu, L. J. Huo, Y. Chen, and B. J. Huo, "Overburden failure height of superhigh seam by fully mechanized caving method," Journal of China Coal Society, vol. 39, no. 5, pp. 816-821, 2014.
[4] H. W. Mu, Y. S. Bao, D. Z. Song, and D. F. Su, "Investigation of strong strata behaviors in the close-distance multiseam coal pillar mining," Shock and Vibration, vol. 2021, Article ID 1263275, 14 pages, 2021.

[5] S. C. Li, Q. Wang, H. T. Wang et al., "Model test study on surrounding rock deformation and failure mechanisms of deep roadways with thick top coal," Tunnelling and Underground Space Technology, vol. 47, pp. 52-63, 2015.

[6] K. Wu, G.-L. Cheng, and D.-W. Zhou, "Experimental research on dynamic movement in strata overlying coal mines using similar material modeling," Arabian Journal of Geosciences, vol. 8, no. 9, pp. 6521-6534, 2015.

[7] J. Wang, J. Zhang, and Z. Li, "A new research system for caving mechanism analysis and its application to sublevel topcoal caving mining," International Journal of Rock Mechanics and Mining Sciences, vol. 88, pp. 273-285, 2016.

[8] H. Wang, Y. Jiang, Y. Zhao, J. Zhu, and S. Liu, "Numerical investigation of the dynamic mechanical state of a coal pillar during longwall mining panel extraction," Rock Mechanics and Rock Engineering, vol. 46, no. 5, pp. 1211-1221, 2013.

[9] J. X. Yang, C. Y. Liu, B. Yu, and F. F. Wu, "The effect of a multi-gob, pier-type roof structure on coal pillar load-bearing capacity and stress distribution," Bulletin of Engineering Geology and the Environment, vol. 74, no. 4, pp. 1-7, 2015.

[10] L. He and Q. B. Zhang, "Numerical investigation of arching mechanism to underground excavation in jointed rock mass," Tunnelling and Underground Space Technology, vol. 50, pp. 54-67, 2015.

[11] L. Jiang, A. Sainoki, H. S. Mitri, N. Ma, H. Liu, and Z. Hao, "Influence of fracture-induced weakening on coal mine gateroad stability," International Journal of Rock Mechanics and Mining Sciences, vol. 88, pp. 307-317, 2016.

[12] P. Małkowski, "The impact of the physical model selection and rock mass stratification on the results of numerical calculations of the state of rock mass deformation around the roadways," Tunnelling and Underground Space Technology, vol. 50, pp. 365-375, 2015.

[13] X. Wang, S. Li, Z. Xu et al., "An interval fuzzy comprehensive assessment method for rock burst in underground caverns and its engineering application," Bulletin of Engineering Geology and the Environment, vol. 78, no. 7, pp. 5161-5176, 2019.

[14] H. Mohammadi, M. A. Ebrahimi Farsangi, H. Jalalifar, and A. R. Ahmadi, "A geometric computational model for calculation of longwall face effect on gate roadways," Rock Mechanics and Rock Engineering, vol. 49, no. 1, pp. 303-314, 2016.

[15] H. Kang, H. Lv, X. Zhang, F. Gao, Z. Wu, and Z. Wang, "Evaluation of the ground response of a pre-driven longwall recovery room supported by concrete cribs," Rock Mechanics and Rock Engineering, vol. 49, no. 3, pp. 1025-1040, 2016.

[16] Z. Li, S. C. Yu, W. Zhu et al., "Dynamic loading induced by the instability of voussoir beam structure during mining below the slope," International Journal of Rock Mechanics and Mining Sciences, vol. 132, Article ID 104343, 2020.

[17] Z. Cao and Y. Zhou, "Research on coal pillar width in roadway driving along goaf based on the stability of key block," Computer Materials Continua, vol. 48, no. 2, pp. 77-90, 2015.

[18] A. Osouli and B. Moradi Bajestani, "The interplay between moisture sensitive roof rocks and roof falls in an illinois underground coal mine," Computers and Geotechnics, vol. 80, pp. 152-166, 2016.

[19] A. K. Verma and D. Deb, "Numerical analysis of the interaction between hydraulic powered support and surrounding rock strata at Indian longwall faces," in Proceedings of the 12th 
International Conference of International Association for Computer Methods and Advances in Geomechanics (IACMAG), Goa, India, October 2008.

[20] B. X. Huang, Y. Z. Wang, and S. G. Cao, "Cavability control by hydraulic fracturing for top coal caving in hard thick coal seams," International Journal of Rock Mechanics and Mining Sciences, vol. 74, pp. 75-57, 2015.

[21] X. Feng, N. Zhang, S. Yang, and F. He, "Mechanical response of fully bonded bolts under cyclic load," International Journal of Rock Mechanics and Mining Sciences, vol. 109, pp. 138-154, 2018.

[22] Y. Lu and L. Wang, "Numerical simulation of mining-induced fracture evolution and water flow in coal seam floor above a confined aquifer," Computers and Geotechnics, vol. 67, pp. 157-171, 2015.

[23] R. Gu and U. Ozbay, "Numerical investigation of unstable rock failure in underground mining condition," Computers and Geotechnics, vol. 63, pp. 171-182, 2015.

[24] S.-Q. Yang, M. Chen, H.-W. Jing, K.-F. Chen, and B. Meng, "A case study on large deformation failure mechanism of deep soft rock roadway in Xin'an coal mine, China," Engineering Geology, vol. 217, pp. 89-101, 2017.

[25] G.-L. Feng, X.-T. Feng, B.-R. Chen, Y.-X. Xiao, and Y. Yu, “A microseismic method for dynamic warning of rockburst development processes in tunnels," Rock Mechanics and Rock Engineering, vol. 48, no. 5, pp. 2061-2076, 2015.

[26] X. W. Feng, N. Zhang, F. Xue, and Z. Xie, "Practices, experience, and lessons learned based on field observations of support failures in some Chinese coal mines," International Journal of Rock Mechanics and Mining Sciences, vol. 123, Article ID 104097, 2019.

[27] N. Falaknaz, M. Aubertin, and L. Li, "Numerical analyses of the stress state in two neighboring stopes excavated and backfilled in sequence," International Journal of Geomechanics, vol. 15, no. 6, Article ID 4015005, 2015.

[28] M. Fraldi and F. Guarracino, "Analytical solutions for collapse mechanisms in tunnels with arbitrary cross sections," International Journal of Solids and Structures, vol. 47, no. 2, pp. 216-223, 2010.

[29] Z. Zhang, J. Bai, Y. Chen, and S. Yan, “An innovative approach for gob-side entry retaining in highly gassy fullymechanized longwall top-coal caving," International Journal of Rock Mechanics and Mining Sciences, vol. 80, pp. 1-11, 2015.

[30] W. Gao and M. Ge, "Stability of a coal pillar for strip mining based on an elastic-plastic analysis," International Journal of Rock Mechanics and Mining Sciences, vol. 87, pp. 23-28, 2016. 